University for Business and Technology in Kosovo

UBT Knowledge Center

UBT International Conference

2017 UBT International Conference

Oct 28th, 9:00 AM - 10:30 AM

\title{
The changes in colour of biscuits during baking depending on time and different proportion of barley flour
}

\author{
Viktorija Stamatovska \\ St. Kliment Ohridski University, vikistam2@gmail.com \\ Gjore Nakov \\ University of Ruse \\ Ivan Dimov \\ Trakia University \\ Ira Traneva \\ Trakia University \\ Tatjana Kalevska \\ St. Kliment Ohridski University
}

See next page for additional authors

Follow this and additional works at: https://knowledgecenter.ubt-uni.net/conference

Part of the Food Science Commons

\section{Recommended Citation}

Stamatovska, Viktorija; Nakov, Gjore; Dimov, Ivan; Traneva, Ira; Kalevska, Tatjana; and Uzunoska, Zora, "The changes in colour of biscuits during baking depending on time and different proportion of barley flour" (2017). UBT International Conference. 165.

https://knowledgecenter.ubt-uni.net/conference/2017/all-events/165

This Event is brought to you for free and open access by the Publication and Journals at UBT Knowledge Center. It has been accepted for inclusion in UBT International Conference by an authorized administrator of UBT Knowledge Center. For more information, please contact knowledge.center@ubt-uni.net. 


\section{Presenter Information}

Viktorija Stamatovska, Gjore Nakov, Ivan Dimov, Ira Traneva, Tatjana Kalevska, and Zora Uzunoska 


\title{
The changes in colour of biscuits during baking depending on time and different proportion of barley flour
}

\author{
Viktorija Stamatovska ${ }^{*}$, Gjore Nakov ${ }^{2}$, Ivan Dimov $^{3}$, Ira Taneva $^{3}$ \\ Tatjana Kalevska ${ }^{1}$, Zora Uzunoska ${ }^{1}$ \\ ${ }^{1}$ Faculty of Technology and Technical Science - Veles, University "St.Kliment Ohridski”- \\ Bitola, Dimitar Vlahov bb,1400 Veles, R. Macedonia \\ 2 Department of Biotechnology and Food Technology, University of Ruse “Angel Kanchev”, \\ Branch Razgrad, Aprilsko vastanie Blvd. 47, Razgrad 7200, Bulgaria \\ 3 Faculty of Technics and Technologies - Yambol, Trakia University - Stara Zagora, Graf \\ Ignatiev Str. 38, 8600, Yambol, Bulgaria \\ *vikistam2@gmail.com
}

\begin{abstract}
Biscuits hold an important position in food industry due to variety of taste, nutrition, crispiness and digestibility. The nutritional value of biscuits can be enhanced by fortification with a wide variety of protein rich cereal such as barley. Colour is essential to the manufacture of biscuits of good quality. During baking, complex chemical reactions take place in the biscuits, such as the Maillard reaction and caramelization. The aim of this study was to evaluate the changes in colour of biscuits during baking. Biscuits were produced according to AACC 10-50D method. Wheat flour was replaced with barley flour at varying levels $(30,50,70$ and 100\%) in biscuit formulations. Color measurement of biscuits was carried out using a colorimeter on the basis of CIE L*, a*, b* color system. Some of the biscuits were stored in room temperature and change of their color was determined after 6 and 12 months.
\end{abstract}

Keywords: Biscuits, Baking, Colour

\section{INTRODUCTION}

Biscuits are a baked product based on wheat flour. Generally, soft wheat flour is recommended to produce biscuits. Soft wheat flour is preferred due to its low hydration properties, low protein content of $8-10 \%$, small level of starch damage and arabinoxylans and weak gluten network [1]. The composition of biscuits includes fats and sweeteners [2], as well as various enhancers and other additives, and because of this, they differ in the type, composition, mass, consistency, structure and technology of production [3].

Biscuits appear on the market, which are produced by mixing together wheat flour and flour from other cereals such as rye, oats, buckwheat, corn, barley, etc. Barley is an important cereal crop that is an excellent source of soluble and insoluble dietary fibers ( $\beta$-glucans, arabinoxylans) and other bioactive compounds such as vitamin E, B-complex vitamins, enzymes, minerals and phenolic compounds [4-8]. The well-known health benefits of barley consumption [8-11] have increased the barley processing and barley requirements in the new biscuits formulations. Many authors, who examined the quality characteristics of crackers produced using barley flour together with wheat flour, concluded that barley flour improves their quality [6, 12-14].

Colour is a characteristic of food products, which is first noticed and directly transformed into a positive or negative sign of the overall quality of the product. During the cooking of biscuits, the surface colour changes as a result of complex chemical reactions in the dough, such as Maillard 
reaction and caramelization. The colour change depends on the composition of the dough, i.e. the type of flour used, the percentage and activity of the water, the sugar content, the $\mathrm{pH}$ value, etc. Different types of flour have a different colour, different gluten quality, that affect the dough, shape and surface of the finished product. On the other hand, the speed of colour creation varies depending on the conditions of the process during baking (temperature, baking time) $[14,15]$. Considering the previously stated findings, we thought that it would be of particular interest to determine how the baking time and the different percentage of barley flour affect the colour change of the biscuits.

\section{MATERIALS AND METHODS}

To produce the biscuits, barley flour was produced by grinding the barley (OSK-6-24/2-12) into a laboratory mills (IKA MF10) at the Institute for Cereals, Osijek, Croatia. White wheat flour T550 and other raw materials were purchased from local stores.

The biscuits were produced in the laboratory of Josip Juraj Strossmayer University of Osijek, Faculty of Food Technology, Osijek, Croatia, in accordance with the AACC Method 10-50D [16]. Five kinds of biscuits were produced: basic control biscuits (100\% wheat flour) and biscuits in which wheat flour was partially and completely replaced with barley flour $(30 \%, 50 \%, 70 \%$ and $100 \%$ barley flour).

The biscuits were baked in a convection oven (Wiesheu Minimat Zibo, Wiesheu GmbH, Germany), at a temperature of $205^{\circ} \mathrm{C}$. The change in the colour of the biscuits was monitored during a time interval of 5 to 10 minutes baking, at every minute. Part of the biscuits that were baked for 10 minutes were stored at room temperature and after 6 and 12 months of storage a change in the colour of their surface was determined.

The measurement of the colour of the biscuits (at 5 different places on the surface) was evident on the basis of CIE L*, a*, $b^{*}$ color system using a colorimeter (Konica Minolta Chroma Meter CR-400, Japan), and the calculations for the total colour difference (colour change, $\Delta \mathrm{E}$ ) are made according to the described from Budžaki et al., [17].

The relation between the calculated value $\Delta \mathrm{E}$ and the human eye tolerance for perceiving differences between colours is given in Table 1 [18].

Table 1. Ratio between calculated values $\Delta \mathrm{E}$ and the tolerance of the human eye for noticing color difference [18]

\begin{tabular}{|l|c|c|c|c|c|}
\hline $\begin{array}{c}\text { Total colour } \\
\text { difference }(\Delta \mathrm{E})\end{array}$ & $<0,2$ & $0,2-1$ & $1-3$ & $3-6$ & $>6$ \\
\hline Meaning & $\begin{array}{c}\text { not } \\
\text { visible }\end{array}$ & $\begin{array}{c}\text { hardly } \\
\text { visible }\end{array}$ & $\begin{array}{c}\text { slightly } \\
\text { visible }\end{array}$ & visible & very visible \\
\hline
\end{tabular}

On the day of production, all types of biscuits were scanned using the Epson Perfection V500 Photo Scanner

Data have been statistically processed and shown with the help of Microsoft Office Excel 2016. The relation between the share of barley flour in the produced biscuits and the colour change for the baking time is expressed through Pearson's correlation coefficient $(\mathrm{R})$ and then the statistical significance is determined $(\mathrm{p}<0.05)$ [19-21]. 


\section{RESULTS AND DISCUSSION}

Colour is one of the most important visual changes occurring during food processing. During baking simultaneous heat and mass transfer occur due to elevated temperatures. Heat is transferred from the hot air to the product surface by convection and throughout the product by conduction while the moisture evaporates from the product. These processes influence the qualitative parameters of cookies including colour formation. Browning is the final step of both the Maillard reaction and caramelization, one of the end-points of the baking process and the final result of sugar degradation during baking [17].

Results of the conducted analysis are shown graphically.

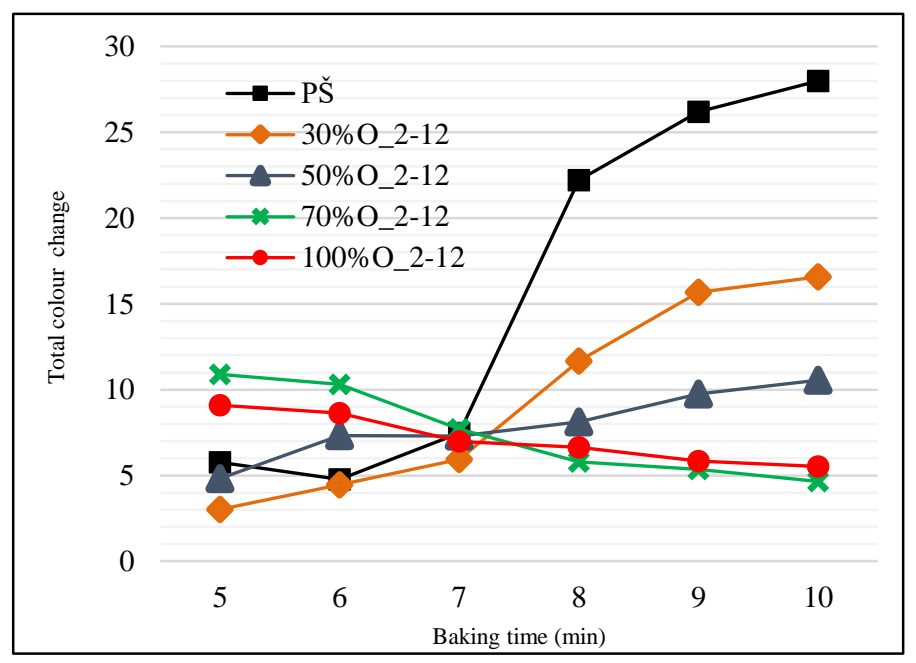

Fig. 1. Colour changes of biscuits during the baking process

Figure 1 shows the results of the total colour difference $(\Delta \mathrm{E})$ of the produced biscuits: a control sample with $100 \%$ wheat flour and biscuits in which partial and complete replacement of wheat with barley flour $30 \%, 50 \%, 70 \%$ и $100 \%$ barley flour) is made on the day of manufacture. Very visible colour change $(\Delta \mathrm{E}>6)$ can be noticed in biscuits with $70 \%$ barley flour $(\Delta \mathrm{E}=10.89)$ and $100 \%$ barley flour $(\Delta \mathrm{E}=9.09)$ after 5 minutes of baking and it decreases with increasing baking time (6 min. $-10 \mathrm{~min} . / \Delta \mathrm{E}=10.31-4.46 \& 6 \mathrm{~min} .-10 \mathrm{~min} . / \Delta \mathrm{E}=8.64-5.52$, respectively). This change is noticed later in other biscuits. In the control biscuits (100\% wheat flour), a very visible colour change can be seen after 7 minutes of baking $(\Delta \mathrm{E}=7,47)$ and this change increases with the increase of baking time $(8 \mathrm{~min} . / \Delta \mathrm{E}=22.21,9 \mathrm{~min} . / \Delta \mathrm{E}=26.20 \& 10 \mathrm{~min} . / \Delta \mathrm{E}=27.98)$, which is contrary to colour change in biscuits with $70 \%$ barley flour and $100 \%$ barley flour.

Also, on the day of production all types of biscuits are scanned every minute during a baking time interval of 5 to 10 minutes (Figure 2). From Figure 2 it can be seen that in different biscuits (control sample, $30 \%, 50 \%, 70 \%$ и $100 \%$ barley flour), colour change occurs at different times during baking. 


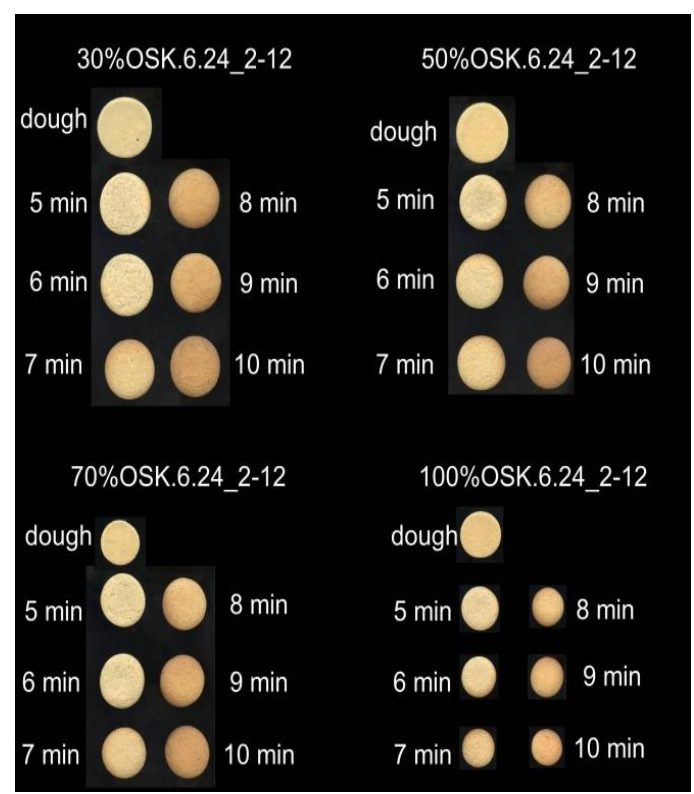

Fig. 2. Colour of dough and biscuits on the day of production

The results of the total colour difference $(\Delta \mathrm{E})$ of biscuits that were baked for 10 minutes and stored at room temperature for 6 and 12 months are shown in Figure 3. From the results shown, it can be seen that only in biscuits with $70 \%$ barley flour there is a visible colour change $(\Delta \mathrm{E}=3$ 6) after 6 and 12 months of storage ( $3.26 \& 3.05$, respectively). In the remaining biscuits, after 6 and 12 months of storage, very visible changes in colour can be observed $(\Delta \mathrm{E}>6)$, with the largest being in biscuits with $100 \%$ wheat flour (6 month/ $\Delta \mathrm{E}=16.49$ and $12 \mathrm{month} / \Delta \mathrm{E}=14.29)$.

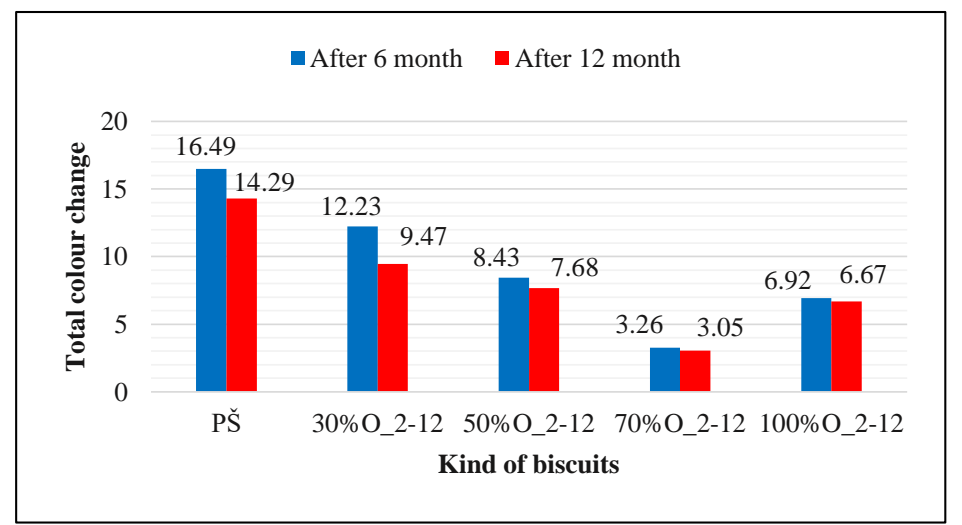

Fig. 3. Colour changes of biscuits after 6 and 12 months of storing (baking process of $10 \mathrm{~min}$.)

If we compare the total colour difference of biscuits (baked 10 minutes) on the day of production (Figure 1) with the total colour difference of the same biscuits after 6 and 12 months of storage 
(Figure 3) it can be concluded that there is generally a tendency in reducing the colour change by increasing the time of storage.

The obtained results from the made correlation analysis are shown graphically (Figure 4-9).

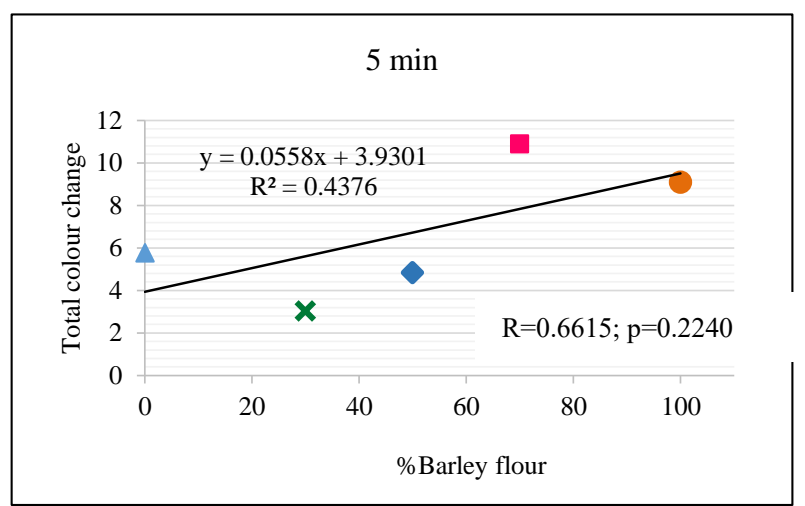

Fig. 4. Correlation between the content of barley flour in the biscuits after $5 \mathrm{~min}$. of baking and the total colour change

The resulting correlation coefficient between the content of barley flour in the examined samples of biscuits after $5 \mathrm{~min}$. of baking and the total colour difference $(\mathrm{R}=0.6615)$, suggest a moderate positive correlation, meaning that there is a tendency for high variable value of the content of barley flour in the biscuits to go with high variable value of the total colour difference and vice versa (Figure 4).

The achieved value of the coefficient of correlation between the content of barley flour in the examined samples of biscuits after 6 min. of baking and the total color change given in Figure 5 $(\mathrm{R}=0.8137)$ show that there is a strong positive correlation, which means that high variable value of the content of barley flour in the biscuits goes with high variable value of the total color change (and vice versa).

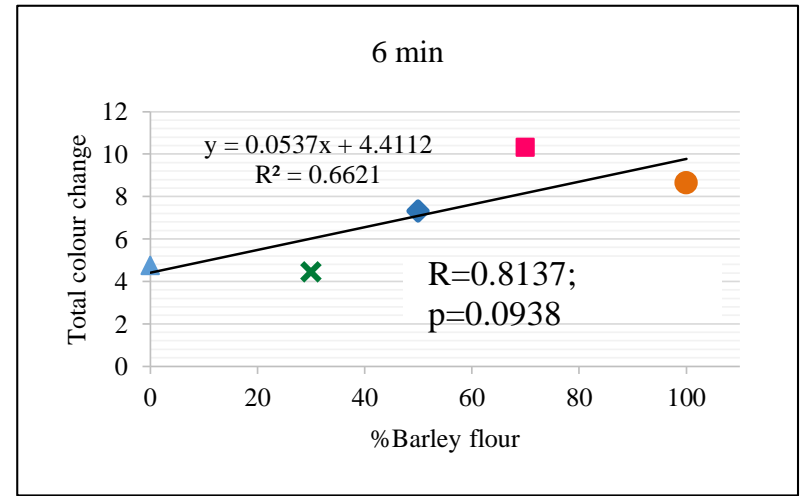

Fig. 5. Correlation between the content of barley flour in the biscuits after $6 \mathrm{~min}$. of baking and the total colour change

Regarding the examined samples of biscuits after 7 min of baking, the value of $\mathrm{R}$ is 0.1021 (Figure 6). Although it is technically a positive correlation, the relationship between the variables is weak. 


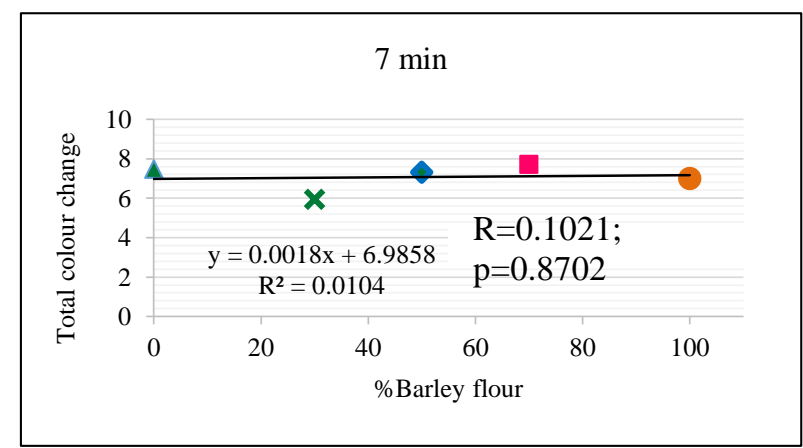

Fig. 6. Correlation between the content of barley flour in the biscuits after $7 \mathrm{~min}$. of baking and the total colour change

The achieved value of the coefficient of correlation between the content of barley flour in the examined samples of biscuits after $8 \mathrm{~min} ., 9 \mathrm{~min}$ and $10 \mathrm{~min}$. of baking and the total color change is given in Figure 7, Figure 8 and Figure $9(R=-0.8762, R=-0.9270$ and $R=-0.9307$, respectively). It refers to the strong negative correlation, which means that high variable value of the content of barley flour in the biscuits to go with low variable value of the total colour change (and vice versa).

Significant difference was noted only after $9 \mathrm{~min}$. and $10 \mathrm{~min}$. of baking $(\mathrm{p}<0.05)$.

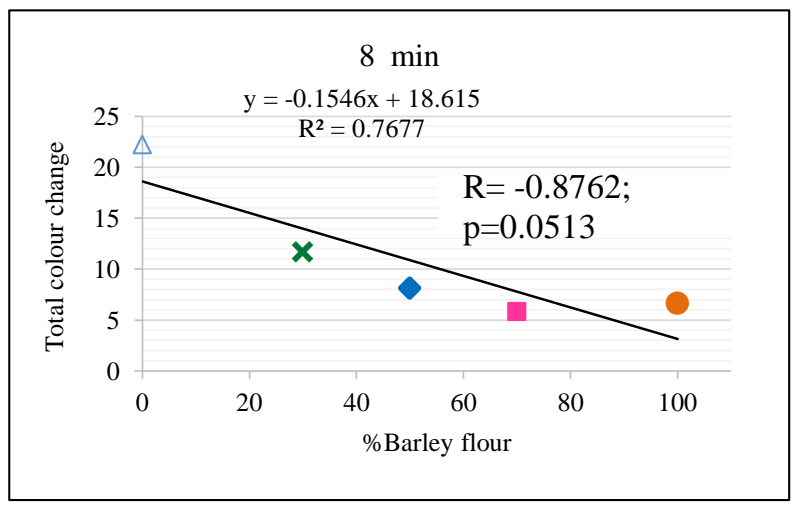

Fig. 7. Correlation between the content of barley flour in the biscuits after $8 \mathrm{~min}$. of baking and the total colour change 


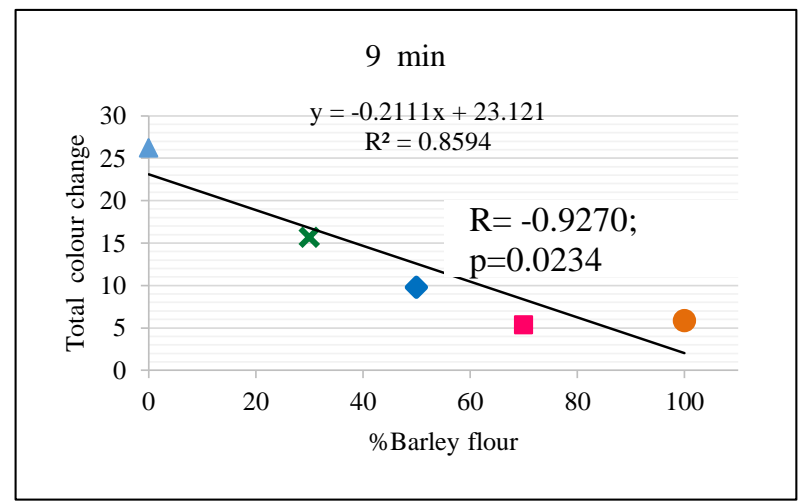

Fig. 8. Correlation between the content of barley flour in the biscuits after $9 \mathrm{~min}$. of baking and the total colour change

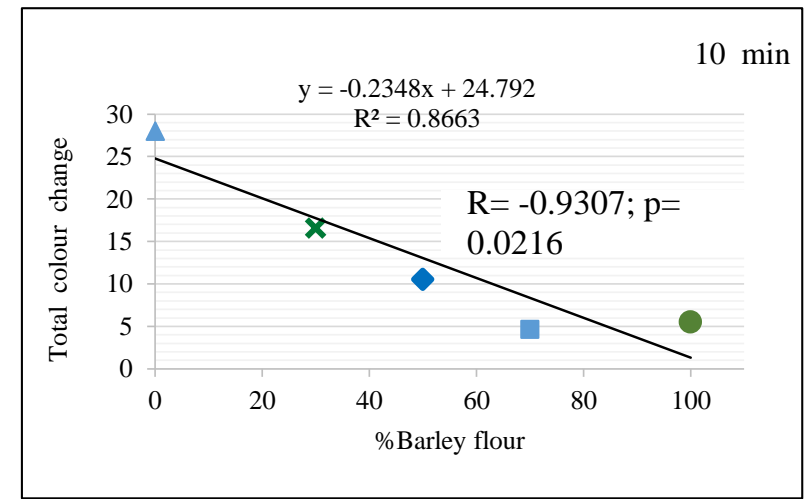

Fig. 9. Correlation between the content of barley flour in the biscuits after $10 \mathrm{~min}$. of baking and the total colour change

\section{CONCLUSION}

On the basis of the analysis conducted it can be concluded that:

In biscuits with $70 \%$ barley flour $(\Delta \mathrm{E}=10.89)$ and $100 \%$ barley flour $(\Delta \mathrm{E}=9.09)$, very visible colour change happens after the 5 th minute of baking, while with other biscuits this change occurs later during the baking.

In biscuits with $100 \%$ barley flour, the colour change decreases during the baking, and in biscuits $100 \%$ wheat flour, the total colour difference increases with an increase in the baking time.

In biscuits stored for 6 and 12 months, there is generally a tendency to reduce colour change by increasing the time of storage.

There is a positive correlation between the content of barley flour in the examined biscuit samples after 5, 6 and 7 min. of baking and the total colour change. By increasing the content of barley flour in biscuits, the overall colour change is also increased. 
There is a negative correlation between the content of barley flour in the examined samples of biscuits 8,9 and $10 \mathrm{~min}$. of baking and total colour change. By increasing the content of barley flour in biscuits, the overall colour change is reduced.

\section{REFERENCES}

1. Hamed, A.: Effect of barley flour rich in $\beta$-Glucan on rheological properties of frozen dough and quality of bread and cookies. Master Thesis. University of Guelph, Ontario, Canada (2013)

2. $\quad$ Cukelj, N.: Enriched cereal products as a source of bioactive compounds and their consumer acceptability. PhD thesis. University of Zagreb, Faculty of Food Technology and Biotechnology, Zagreb (2013)

3. Čnova, V., Karađov, G.: Technology of Bakery and Confectionery Products, Plovdiv (2014)

4. Belcredi, B. N., Ehrenbergerová, J., S. Běláková, S., Vaculová, K.: Barley Grain as a Source of Health-Beneficial Substances. Czech J. Food Sci., 27, Special Issue (2009) S242-S244

5. Lathia, N.: Instrumental and Sensory Characteristics of a Baked Product Containing Barley Flour with Varying Amounts of Beta-Glucan and Sugar Substitute. Master Thesis. Graduate School-New Brunswick Rutgers, The State University of New Jersey (2011)

6. Sharma, P., Kotari, L. S.: Barley: Impact of processing on physicochemical and thermal properties-A review. Food Reviews International, 33(4) (2017) 359-381

7. Djurle, S.: Carbohydrate quality of barley products with focus on $\beta$-glucan. Doctoral thesis. Swedish University of Agricultural Sciences (2017)

8. Baik, B., Newman, W.C., Newman, K.R.: Food Uses of Barley. In: Ullrich, E.S. (ed.): Barley: Production, improvement, and uses. Wiley-Blackwell, Ames, IA, USA (2011)

9. Malik, X. A: Nutrient uptake, transport and translocation in cereals: influences of environment and farming conditions. Introductory Paper at the Faculty of Landscape Planning, Horticulture and Agricultural Science 2009:1, Swedish University of Agricultural Sciences (2009)

10. Aldughpassi, A.: Physiological Effects of Barley: Examining the Effects of Cultivar, Processing and Food Form on Glycemia, Glycemic Index, Satiety and the Physico-Chemical Properties of $\beta$-glucan. Doctor Thesis. University of Toronto (2013)

11. Arshad, U., Anjum, M. F., Rehman, U. S., Sohaib, M.: Development and characterization of multigrain cookies, Pakistan Journal of Food Sciences, 24(1) (2014) 1-5

12. Frost, J. D., Adhikari, K., S. Lewis, S. D. Effect of barley flour on the physical and sensory characteristics of chocolate chip cookies. J Food Sci Technol, 48(5) (2011) 569-576

13. Gupta, M., Bawa, S. A., Abu-Ghannam, N.: Effect of barley flour and freeze-thaw cycles on textural nutritional and functional properties of cookies. Food and bioproducts processing, 89 (2011) 520-527

14. Sharma, P., Gujral, S. H.: Cookie making behavior of wheat-barley flour blends and effects on antioxidant properties. LWT - Food Science and Technology, 55 (2014) 301-307

15. Ameur, A. L., Trystram, G., Birlouez-Aragon, I.: Accumulation of 5-hydroxymethyl2 furfural in cookies during the backing process: Validation of an extraction method. Food Chemistry, 98 (2006) 790-796 
16. AACC International. Approved Methods of Analysis, 10th Ed. Method 10-50D. Baking Quality of Cookie Flour, Approved Methods of the Association of Cereal Chemists, AACC International, St. Paul, MN, U.S.A. (2000)

17. Budžaki, S., Komlenić, K. D., Čačić, L. J., Čačić, F., Jukić, M., Kožul, Ž.: Influence of cookies composition on temperature profiles and qualitative parameters during baking. Croat.J.Food. Sci. Technol, 6 (2) (2014) 72-78

18. Bošnjaković, N.: Application of Digital Image Analysis to Colours changes on tea biscuits made from wheat flour. Graduate thesis, Faculty of Food Technology Osijek, University Josip Juraj Strossmayer, Osijek, Croatia (2014)

19. Kotarski, I.: The observation of cookies qualitative parameters prepared with lard. Graduate thesis, Faculty of Food Technology Osijek, University Josip Juraj Strossmayer, Osijek, Croatia (2015)

20. Social Science Statistics: Pearson Correlation Coefficient Calculator, <URL: http://www.socscistatistics.com/tests/pearson/Default2.aspx. Accessed 18.09.2017.

21. Social Science Statistics: $p$ Value from Pearson (R) Calculator, <URL: http://www.socscistatistics.com/pvalues/pearsondistribution.aspx. Accessed 18.09.2017. 